\title{
Magnesium isotope fractionation during carbonatite magmatism at Oldoinyo Lengai, Tanzania
}

Wang-Ye Li ${ }^{\mathrm{a}, *}$, Fang-Zhen Teng ${ }^{\mathrm{b}, * *}$, Ralf Halama ${ }^{\mathrm{c}}$, Jörg Keller ${ }^{\mathrm{d}}$, Jurgis Klaudius ${ }^{\mathrm{d}}$

${ }^{a}$ CAS Key Laboratory of Crust-Mantle Materials and Environments, School of Earth and Space Sciences, University of Science and Technology of China, Hefei, Anhui 230026, China

b Isotope Laboratory, Department of Earth and Space Sciences, University of Washington, Seattle, WA 98195-1310, USA

c School of Physical and Geographical Sciences, Keele University, Keele, Staffordshire, ST5 5BG, UK

d Institut für Geowissenschaften, Mineralogie-Geochemie, Albert-LudwigsUniversität Freiburg, Albertstrasse 23b, 79104 Freiburg, Germany

Revised version (March 17, 2016)

* Corresponding author at: CAS Key Laboratory of Crust-Mantle Materials and Environments, School of Earth and Space Sciences, University of Science and Technology of China, Hefei, Anhui 230026, China.

** Corresponding author.

E-mail addresses: wyli@ustc.edu.cn (W.-Y. Li), fteng@u.washington.edu (F.-Z. Teng). 


\section{Abstract}

To investigate the behaviour of $\mathrm{Mg}$ isotopes during carbonatite magmatism, we analyzed $\mathrm{Mg}$ isotopic compositions of natrocarbonatites and peralkaline silicate rocks from Oldoinyo Lengai, Tanzania. The olivine melilitites from the vicinity of Oldoinyo Lengai have homogeneous and mantle-like $\mathrm{Mg}$ isotopic compositions $\left(\delta^{26} \mathrm{Mg}\right.$ of -0.30 to $-0.26 \%$ ), indicating limited $\mathrm{Mg}$ isotope fractionation during mantle melting. The highly evolved peralkaline silicate rocks not related to silicate-carbonatite liquid immiscibility, including phonolites from the unit Lengai I, combeite-wollastonite nephelinites (CWNs) from the unit Lengai II A and carbonated combeite-wollastonite-melilite nephelinites (carbCWMNs), have $\delta^{26} \mathrm{Mg}$ values (from -0.25 to $-0.10 \%$ ) clustered around the mantle value. By contrast, the CWNs from the unit Lengai II B, which evolved from the silicate melts that were presumably generated by silicate-carbonatite liquid immiscibility, have heavier $\mathrm{Mg}$ isotopes $\left(\delta^{26} \mathrm{Mg}\right.$ of -0.06 to $+0.09 \%$ ). Such a difference suggests $\mathrm{Mg}$ isotope fractionation during liquid immiscibility and implies, based on mass-balance calculations, that the original carbonatite melts at Lengai were isotopically light. The variable and positive $\delta^{26} \mathrm{Mg}$ values of natrocarbonatites (from +0.13 to $+0.37 \%$ ) hence require a change of their $\mathrm{Mg}$ isotopic compositions subsequent to liquid immiscibility. The negative correlations between $\delta^{26} \mathrm{Mg}$ values and contents of alkali and alkaline earth metals of natrocarbonatites suggest $\mathrm{Mg}$ isotope fractionation during fractional crystallization of carbonatite melts, with heavy $\mathrm{Mg}$ isotopes 
23 enriched in the residual melts relative to fractionated carbonate minerals.

24 Collectively, significant $\mathrm{Mg}$ isotope fractionation may occur during both

25 silicate-carbonatite liquid immiscibility and fractional crystallization of carbonatite

26 melts, making $\mathrm{Mg}$ isotopes a potentially useful tracer of these processes relevant to

27 carbonatite petrogenesis.

28

29

30 Keywords: magnesium isotopes; isotope fractionation; carbonatite magmatism;

31 liquid immiscibility; Oldoinyo Lengai

32 


\section{Introduction}

Magmatism is an important process responsible for chemical differentiation of the Earth. Knowledge on the fractionation behaviour of stable isotopes during magmatic processes is the prerequisite for applying them as tracers of source characteristics or magmatic evolution. Magnesium is the most abundant metallic element in the mantle and, hence, the $\mathrm{Mg}$ isotope systematics of mafic and ultramafic igneous rocks have received wide attention. Previous studies demonstrated that $\mathrm{Mg}$ isotopic compositions of komatiites, mid-ocean ridge basalts and ocean island basalts $\left(\delta^{26} \mathrm{Mg}\right.$ of -0.42 to $-0.15 \%$, Teng et al., 2007, 2010; Bourdon et al., 2010; Dauphas et al., 2010) were similar to those of mantle peridotites $\left(\delta^{26} \mathrm{Mg}\right.$ of -0.48 to $-0.06 \%$, Handler et al., 2009; Yang et al., 2009; Bourdon et al., 2010; Teng et al., 2010; Huang et al., 2011; Pogge von Strandmann et al., 2011; Xiao et al., 2013; Lai et al., 2015). This indicates limited Mg isotope fractionation during mantle melting and subsequent basaltic magma differentiation and, hence, $\mathrm{Mg}$ isotopic compositions of basalts can be used to constrain those of their mantle sources (Teng et al., 2007, 2010; Bourdon et al., 2010).

Carbonatites are another type of mantle-derived igneous rocks. In contrast to the small equilibrium $\mathrm{Mg}$ isotope fractionation between olivine, clinopyroxene and orthopyroxene (Handler et al., 2009; Yang et al., 2009; Huang et al., 2011; Pogge von Strandmann et al., 2011; Xiao et al., 2013; Lai et al., 2015), large equilibrium $\mathrm{Mg}$ isotope fractionation between olivine and magnesite/dolomite at high 
temperatures has been revealed by both theoretical calculations (Schauble, 2011) and experimental work (Macris et al., 2013). Such a difference implies the possibility of different behaviour of $\mathrm{Mg}$ isotopes between carbonatite magmatism and silicate magmatism, as in the case of Fe isotope systematics (Johnson et al., 2010). Therefore, studies on $\mathrm{Mg}$ isotopic characteristics of carbonatites may not only improve our understanding of high-temperature $\mathrm{Mg}$ isotope fractionation but also exploit new applications. However, to our knowledge, $\mathrm{Mg}$ isotopic data of carbonatites have been reported in only two papers. Sun et al. (2012) found that two carbonatite samples from Bayan Obo, China, had Mg isotopic compositions $\left(\delta^{26} \mathrm{Mg}=-0.34 \pm 0.11 \%\right.$ and $-0.14 \pm 0.18 \%$ ) similar to that of the pristine mantle $\left(\delta^{26} \mathrm{Mg}\right.$ ranging from -0.48 to $-0.06 \%$ with an estimated average value of $-0.25 \pm 0.07 \%$, 2SD, Teng et al., 2007, 2010; Handler et al., 2009; Yang et al., 2009; Bourdon et al., 2010; Dauphas et al., 2010; Huang et al., 2011; Pogge von Strandmann et al., 2011; Xiao et al., 2013; Lai et al., 2015). Hence, they suggested insignificant $\mathrm{Mg}$ isotope fractionation during carbonatite petrogenesis. By contrast, Ling et al. (2013) observed large Mg isotopic variations $\left(\delta^{26} \mathrm{Mg}\right.$ of -2.28 to $+0.23 \%$ ) in carbonatite samples from the same area. They explained such variations by mixing various proportions of isotopically heavy crustal materials with an isotopically light carbonatite end-member. However, they didn't provide a genetic interpretation of the isotopically light endmember carbonatite, which was originated from the mantle but had $\mathrm{Mg}$ isotopic composition $\left(\delta^{26} \mathrm{Mg}=-2.28 \%\right.$ ) remarkably different from the average $\delta^{26} \mathrm{Mg}$ value of the pristine mantle $(-0.25 \pm 0.07 \%$, $2 \mathrm{SD}$, Teng et al., 2010). These diverging interpretations 
underline the importance of a $\mathrm{Mg}$ isotope study on a set of carbonatite samples that are well characterized in terms of petrology and geochemistry.

In order to investigate the behaviour of $\mathrm{Mg}$ isotopes during carbonatite magmatism, we carried out high-precision $\mathrm{Mg}$ isotopic analyses for natrocarbonatites and peralkaline silicate rocks from Oldoinyo Lengai, Tanzania. Our results demonstrate that compositionally variable silicate rocks not related to silicate-carbonatite liquid immiscibility have $\mathrm{Mg}$ isotopic compositions clustered around the mantle value, whereas silicate rocks petrogenically associated with liquid immiscibility and natrocarbonatites have heavy Mg isotopic compositions. These observations suggest that significant $\mathrm{Mg}$ isotope fractionation may occur during both silicate-carbonatite liquid immiscibility and fractional crystallization of carbonatite melts. Consequently, $\mathrm{Mg}$ isotopic compositions of carbonatites may potentially be used to trace processes (i.e., liquid immiscibility and fractional crystallization) relevant to carbonatite petrogenesis.

\section{Geological settings and samples}

Oldoinyo Lengai is the only active carbonatite volcano on Earth. It lies in the East African Rift Valley in northern Tanzania with volcanological observations more than 100 years (Keller et al., 2010). This volcano consists predominantly (>95 vol.\%) of phonolite and nephelinite lavas and pyroclastics, with natrocarbonatite ashes and lavas in the summit area. Klaudius and Keller (2006) defined three major structural 
units of Oldoinyo Lengai, namely Lengai I (phonolite tuffs and lavas), Lengai II A (nephelinite tuffs and lavas) and Lengai II $B$ (nephelinite tuffs and lavas as well as natrocarbonatite tuffs and lavas). In addition, ashes, lapilli and scoriae with the unique composition of carbonated combeite-wollastonite-melilite nephelinites (carbCWMNs) were erupted during the 2007-2008 explosive activity (Keller et al., 2010). Although olivine melilitites with high $\mathrm{Mg} \#\left[\right.$ molar $\mathrm{Mg} /\left(\mathrm{Mg}+\mathrm{Fe}^{2+}\right) \times$ 100] $>50$ occur in some monogenetic cones in the vicinity of Oldoinyo Lengai (Dawson et al., 1985; Keller et al., 2006; Mattsson, 2012; Mattsson et al., 2013), rocks of primary magma compositions are absent within the Lengai volcanic edifice itself. Silicate rocks and natrocarbonatites at Oldoinyo Lengai are all peralkaline [molar $(\mathrm{Na}+\mathrm{K}) / \mathrm{Al}>1$, Simonetti et al., 1997; Dawson, 1998; Klaudius and Keller, 2006] and are distinctly of mantle origin as indicated by both $\mathrm{Sr}-\mathrm{Nd}-\mathrm{Pb}$ isotopes (Bell and Simonetti, 1996; Bell and Tilton, 2001) and C-O-Li isotopes (Keller and Hoefs, 1995; Halama et al., 2007). Many previous studies have discussed the petrogenetic relationships between olivine melilitites, phonolites, nephelinites and natrocarbonatites at Oldoinyo Lengai, through investigations of natural samples and/or phase equilibrium experiments. A brief summary is given here (Fig. 1).

Olivine melilitites in the vicinity of Oldoinyo Lengai were formed by small degrees (1-2\%) of partial melting of the mantle and were considered to represent the possible primary melts of the Lengai volcano (Peterson and Kjarsgaard, 1995; Keller et al., 2006; Wiedenmann et al., 2010). However, there is a large compositional gap between olivine melilitites $(\mathrm{MgO}>9$ wt\% and $\mathrm{Mg \#}>50$, Keller et al., 2006; 
121

122

Mattsson et al., 2013) and the highly evolved phonolites and nephelinites of the units Lengai I and Lengai II ( $\mathrm{MgO}<2 \mathrm{wt} \%$ and $\mathrm{Mg \#}<31$, Klaudius and Keller, 2006). Moreover, melilitites and nephelinites/phonolites display different $\mathrm{Sr}-\mathrm{Nd}-\mathrm{Pb}$ isotopic signatures (Keller et al., 2006) and opposite variation trends of some major and trace elements (Mattsson et al., 2013). Therefore, olivine melilitites cannot be related directly to nephelinites/phonolites (Mattsson et al., 2013), and parental magmas of the highly evolved nephelinites/phonolites at Lengai remain unknown.

A widely accepted model for natrocarbonatite petrogenesis at Oldoinyo Lengai is immiscible separation of carbonatite melts from $\mathrm{CO}_{2}$-saturated and strongly peralkaline nephelinitic melts (e.g., Peterson, 1990; Church and Jones, 1995; Keller and Spettel, 1995; Kjarsgaard et al., 1995; Dawson, 1998), though other models have been proposed, such as partial melting of fenitized basement (Morogan and Martin, 1985), differentiation from mildly alkalic olivine sövitic magmas (Twyman and Gittins, 1987) and condensation from cognate alkaline fluids (Nielsen and Veksler, 2002). Liquid immiscibility between silicate and carbonatite melts has been directly demonstrated by coexisting silicate and carbonate melt inclusions in nepheline phenocrysts from erupted ashes and in minerals of ijolite xenoliths at Oldoinyo Lengai (Mitchell, 2009; Sekisova et al., 2015). Stratigraphic relationships and $\mathrm{Sr}-\mathrm{Nd}-\mathrm{Pb}$ isotopic data suggest that the combeite- and wollastonite-bearing nephelinites (CWNs) from the unit Lengai II B are petrogenetically related to natrocarbonatites and may represent differentiation products of the conjugate silicate melts from which the original carbonatite melts exsolved (Kjarsgaard et al., 1995; 
Bell and Simonetti, 1996; Dawson, 1998; Klaudius and Keller, 2006). By contrast, phonolites from the unit Lengai I, CWNs from the unit Lengai II A and carbCWMNs of the 2007-2008 activity are assumed to represent silicate melts that did not experience liquid immiscibility (Klaudius and Keller, 2006; Keller et al., 2010). Once immiscibility occurred, the original carbonatite melts efficiently segregated from the conjugate silicate melts due to their low viscosity and density. Subsequent carbonatite magma differentiation at Oldoinyo Lengai was dominated by fractional crystallization of nyerereite $\left(\mathrm{Na}_{2} \mathrm{Ca}\left[\mathrm{CO}_{3}\right]_{2}\right)$ and gregoryite $\left(\left[\mathrm{Na}, \mathrm{Ca}_{x}, \mathrm{~K}\right]_{2-x} \mathrm{CO}_{3}\right.$ ), generating natrocarbonatites (Peterson, 1990; Kjarsgaard et al., 1995; Gittins and Jago, 1998; Mattsson and Caricchi, 2009).

In this study, $\mathrm{Mg}$ isotopes were measured for twenty-two samples, including four olivine melilitites from the vicinity of the Lengai volcano, five phonolites from the unit Lengai I, two CWNs from the unit Lengai II A, three CWNs from the unit Lengai II B, three carbCWMNs of the 2007-2008 activity and five natrocarbonatites. These samples are the same as those studied in previous work (Simonetti et al., 1997; Keller et al., 2006, 2010; Klaudius and Keller, 2006; Halama et al., 2007). Detailed sample descriptions as well as petrological and geochemical aspects of these samples are available therein. As demonstrated in these papers, there is little petrographic evidence for alteration in the investigated samples, except for a few altered combeites in sample OL 804 (Klaudius and Keller, 2006). Both silicate rocks and natrocarbonatites retain their primary igneous mineralogy and do not contain clay minerals. In particular, natrocarbonatites are strongly susceptible to alteration at the 
Earth's surface (e.g., Zaitsev and Keller, 2006). However, the natrocarbonatite samples studied here were collected directly after eruption and their $\mathrm{C}-\mathrm{O}-\mathrm{Li}$ isotopic compositions fall into a restricted field within the "primary igneous carbonatites" (Keller and Hoefs, 1995; Halama et al., 2007). Collectively, the effects of alternation on $\mathrm{Mg}$ isotopic compositions of the samples investigated here can be excluded.

\section{Analytical methods}

Magnesium isotopic analyses were performed at the Isotope Laboratory of the University of Arkansas, Fayetteville, following previously established procedures (Teng et al., 2007, 2010, 2015; Yang et al., 2009; Li et al., 2010; Ling et al., 2013; Teng and Yang, 2014). A brief description is given here.

Whole-rock powders were dissolved in screw-top beakers in a combination of concentrated $\mathrm{HF}-\mathrm{HNO}_{3}-\mathrm{HCl}$. Separation of $\mathrm{Mg}$ was achieved by cation exchange chromatography with Bio-Rad 200-400 mesh AG50W-X8 resin in $1 \mathrm{~mol} \cdot \mathrm{L}^{-1} \mathrm{HNO}_{3}$ media. The Mg column chemistry was performed twice for silicate rocks and four or five times for natrocarbonatites in order to obtain a pure $\mathrm{Mg}$ solution for mass spectrometry. The $\mathrm{Mg}$ yields through column chemistry, based on analyses of $\mathrm{Mg}$ content in the elution collected before and after the $\mathrm{Mg}$ cut, were $>99.8 \%$. To ensure the efficiency of removing $\mathrm{Ca}$ for natrocarbonatites with high $\mathrm{CaO} / \mathrm{MgO}$ ratios (from 25 to 38 , wt/wt), we carried out repeat analyses for natrocarbonatites by using an additional Ca column chemistry with Bio-Rad 200-400 mesh AG50W-X12 resin in 
187

188

$12 \mathrm{~mol} \cdot \mathrm{L}^{-1} \mathrm{HCl}$ media (Ling et al., 2013) after two or three iterations of $\mathrm{Mg}$ column chemistry. The residual content of $\mathrm{Ca}$ in the solution after column chemistry was below the detection limit for $\mathrm{Ca}(\sim 10 \mathrm{ppb})$ by inductively coupled plasma mass spectrometry (ICP-MS). Magnesium isotopic compositions were analyzed by the standard-sample bracketing method using a $\mathrm{Nu}$ Plasma multi-collector inductively coupled plasma mass spectrometry (MC-ICP-MS).

The results are reported in $\delta$-notation in per mil relative to DSM3: $\delta^{\mathrm{X}} \mathrm{Mg}=$ $\left[\left({ }^{\mathrm{X}} \mathrm{Mg} /{ }^{24} \mathrm{Mg}\right)_{\text {sample }} /\left({ }^{\mathrm{X}} \mathrm{Mg} /{ }^{24} \mathrm{Mg}\right)_{\text {DSM3 }}-1\right] \times 1000$, where $\mathrm{X}$ refers to mass 25 or 26. Based on replicate analyses of a seawater sample from Hawaii and an in-house reference solution $\mathrm{KH}$-olivine, the long-term external precision on $\delta^{26} \mathrm{Mg}$ value is $\leq 0.10 \%$ (2SD, Li et al., 2010; Teng et al., 2010, 2015). Both synthetic solutions and reference materials were processed through column chemistry with samples for accuracy check. Multiple analyses of synthetic solutions IL-Mg-1 (concentration ratios of $\mathrm{Mg}: \mathrm{Fe}: \mathrm{Al}: \mathrm{Ca}: \mathrm{Na}: \mathrm{K}: \mathrm{Ti}=1: 1: 1: 1: 1: 1: 0.1$ ) and Carb (concentration ratios of $\mathrm{Ca}: \mathrm{Mg}=100: 1)$ yielded $\delta^{26} \mathrm{Mg}$ values of -0.05 to $-0.01 \%$ (Table 1 ), in agreement with the expected true value of 0.00 . Magnesium isotopic compositions of seawater, the Allende chondrite and the in-house reference solution $\mathrm{KH}-$ olivine analyzed during the course of this study also agree with previously published values (Table 1). These data, combined with the indistinguishable results for repeat analyses of individual samples (Tables 2 and 3), especially of natrocarbonatites that were processed through different column procedures (Fig. 2), assure the accuracy of our data. 


\section{Results}

Magnesium isotopic compositions are reported in Table 1 for synthetic solutions and reference materials, Table 2 for peralkaline silicate rocks, and Table 3 for natrocarbonatites from Oldoinyo Lengai. For reference, some elemental and isotopic data reported in previous studies (Simonetti et al., 1997; Keller et al., 2006, 2010; Klaudius and Keller, 2006; Halama et al., 2007) are also included in Tables 2 and 3. All samples analyzed in this study fall on an isotopic mass-dependent fractionation line with a slope of 0.518 on the Mg three-isotope diagram (Fig. 3). Hence, we only use $\delta^{26} \mathrm{Mg}$ in the subsequent discussions.

Olivine melilitites from the vicinity of Oldoinyo Lengai have homogeneous $\mathrm{Mg}$ isotopic compositions $\left(\delta^{26} \mathrm{Mg}=-0.30\right.$ to $-0.26 \%$, Table 2$)$. The $\delta^{26} \mathrm{Mg}$ values vary from -0.25 to $-0.10 \%$ in phonolites from the unit Lengai I, from -0.14 to $-0.13 \%$ in CWNs from the unit Lengai II A, and from -0.17 to $-0.15 \%$ in carbCWMNs of the 2007-2008 activity, respectively. The overall variation for these rocks from the Lengai volcano is small and all data cluster around the average $\delta^{26} \mathrm{Mg}$ value of the pristine mantle (Fig. 4). By contrast, the $\delta^{26} \mathrm{Mg}$ values of CWNs from the unit Lengai II B (from -0.06 to $+0.09 \%$ ) and of natrocarbonatites (from +0.13 to $+0.37 \%$ ) are higher than the pristine mantle value (Fig. 4).

\section{Discussion}

In this section, we evaluate the behaviour of $\mathrm{Mg}$ isotopes during (1) peralkaline 
silicate magma differentiation, (2) silicate-carbonatite liquid immiscibility, and (3) carbonatite magma differentiation, respectively.

\subsection{Small Mg isotope fractionation during peralkaline silicate magma differentiation}

Olivine melilitites in the vicinity of Oldoinyo Lengai were formed by small degrees (1-2\%) of partial melting of the mantle (Mattsson et al., 2013). They have variable $\mathrm{MgO}$ content and $\mathrm{Mg \#} \mathrm{(from} 15$ to $10 \mathrm{wt} \%$ and 70 to 59, respectively, Table 2) due to the early stages of fractional crystallization of olivine (Keller et al., 2006). However, they have homogeneous and mantle-like $\mathrm{Mg}$ isotopic compositions $\left(\delta^{26} \mathrm{Mg}\right.$ $=-0.30$ to $-0.26 \%$, Table 2), indicating insignificant $\mathrm{Mg}$ isotope fractionation during mantle melting and olivine crystallization. This is consistent with previous suggestions that $\mathrm{Mg}$ isotope fractionation during mantle melting and subsequent basaltic magma differentiation is limited (Teng et al., 2007, 2010; Bourdon et al., 2010).

Phonolites from the unit Lengai I, CWNs from the unit Lengai II A and carbCWMNs of the 2007-2008 activity are considered to represent peralkaline silicate melts that did not experience liquid immiscibility (Klaudius and Keller, 2006; Keller et al., 2010). Despite of their variable $\mathrm{MgO}$ content (from 2.0 to $0.8 \mathrm{wt} \%$ ), these rocks display a relatively narrow range in $\delta^{26} \mathrm{Mg}$ (from -0.25 to $-0.10 \%$ ), barely beyond the average mantle value (Fig. 4). This observation suggests that $\mathrm{Mg}$ 
isotope fractionation during differentiation of highly evolved peralkaline silicate magma, if any, is small. Hence, the silicate melts before liquid immiscibility at Oldoinyo Lengai probably had $\mathrm{Mg}$ isotopic compositions similar to the average mantle value.

\subsection{Significant $\mathrm{Mg}$ isotope fractionation during silicate-carbonatite liquid}

\section{immiscibility}

Combeite-wollastonite nephelinites from the unit Lengai II B are currently believed to result from differentiation of the silicate melts generated by silicate-carbonatite liquid immiscibility (Kjarsgaard et al., 1995; Klaudius and Keller, 2006). Although the detailed differentiation processes from the conjugate silicate melts at the time of immiscibility to CWNs from the unit Lengai II B remain unknown, they would not affect $\mathrm{Mg}$ isotopic composition of the silicate melts since $\mathrm{Mg}$ isotope fractionation during highly evolved peralkaline silicate magma differentiation is small. Hence, the $\delta^{26} \mathrm{Mg}$ values of CWNs from the unit Lengai II B (from -0.06 to $+0.09 \%$ ) are likely to record those of the silicate melts after liquid immiscibility. The difference in $\mathrm{Mg}$ isotopic compositions between the silicate melts before and after immiscibility suggests $\mathrm{Mg}$ isotope fractionation during liquid immiscibility.

Magnesium isotopic mass balance during silicate-carbonatite liquid immiscibility follows: 


$$
\delta^{26} \mathrm{Mg}_{0}=\delta^{26} \mathrm{Mg}_{\mathrm{s}} \times \mathrm{f}_{\mathrm{Mg}, \mathrm{s}}+\delta^{26} \mathrm{Mg}_{\mathrm{c}} \times \mathrm{f}_{\mathrm{Mg}, \mathrm{c}}
$$

276 where $\delta^{26} \mathrm{Mg}_{0}, \delta^{26} \mathrm{Mg}_{\mathrm{s}}$ and $\delta^{26} \mathrm{Mg}_{\mathrm{c}}$ are the $\mathrm{Mg}$ isotopic composition of silicate melt

277 before immiscibility and of silicate melt and carbonatite melt after immiscibility,

278 respectively. The $\mathrm{f}_{\mathrm{Mg}, \mathrm{s}}$ and $\mathrm{f}_{\mathrm{Mg}, \mathrm{c}}$ refer to the fraction of $\mathrm{Mg}$ contained in the conjugate

279 silicate and carbonatite melts $\left(\mathrm{f}_{\mathrm{Mg}, \mathrm{s}}+\mathrm{f}_{\mathrm{Mg}, \mathrm{c}}=1\right)$. The heavy $\mathrm{Mg}$ isotopic compositions

280 of CWNs from the unit Lengai II B indicates $\delta^{26} \mathrm{Mg}_{\mathrm{s}}>\delta^{26} \mathrm{Mg}_{0}$, which in turn implies

$281 \delta^{26} \mathrm{Mg}_{\mathrm{c}}<\delta^{26} \mathrm{Mg}_{0}$, i.e., the original carbonatite melts at Lengai were isotopically light 282 (Fig. 4).

283 The inferred preferential partition of heavy $\mathrm{Mg}$ isotopes into silicate melts 284 relative to carbonatite melts during liquid immiscibility is consistent with the 285 direction predicted by theoretical and experimental work on equilibrium 286 inter-mineral $\mathrm{Mg}$ isotope fractionation between silicate and carbonate minerals. For 287 example, theoretical calculations yielded $10^{3} \ln \alpha_{\text {forsterite-magnesite of }+0.21 \% \text { and }}$ $28810^{3} \ln \alpha_{\text {forsterite-dolomite }}$ of $+0.15 \%$ at $1000{ }^{\circ} \mathrm{C}$ (Schauble, 2011), while experimental 289 measurements yielded $10^{3} \ln \alpha_{\text {forsterite-magnesite }}$ of $+0.44 \pm 0.10 \%$ at $600{ }^{\circ} \mathrm{C}$ (Macris et 290 al., 2013). In general, phases with the stronger bonding environment of the cation of 291 interest favor heavier isotopes when thermodynamic equilibrium is achieved (e.g., 292 Bigeleisen, 1965). Hence, the positive $10^{3} \ln \alpha_{\text {forsterite-magnesite/dolomite values reflect }}$ 293 stronger $\mathrm{Mg}-\mathrm{O}$ bonds in forsterite versus weaker bonds in magnesite/dolomite. Such 294 a difference may also exist between silicate melts and carbonatite melts since they 295 also use the $\left[\mathrm{SiO}_{4}\right]^{4-}$ tetrahedra and the $\left[\mathrm{CO}_{3}\right]^{2-}$ group, respectively, as their basic 296 structure units (e.g., Henderson et al., 2006; Vuilleumier et al., 2014). If this is true, 
silicate melts are expected to be enriched in heavy $\mathrm{Mg}$ isotopes relative to carbonatite melts, though silicate melts and carbonatite melts respectively have homogeneous $\mathrm{Mg}$ isotopic compositions due to fast diffusion of isotopes in melts. Such a speculative mechanism of isotope fractionation can be understood on analogy with element partition between immiscible silicate and carbonatite melts, where the concentration of certain elements will be homogeneous among each melt but be different between these two melts due to the different melt structures (e.g., Jones et al., 1995; Martin et al., 2013).

\subsection{Significant $\mathrm{Mg}$ isotope fractionation during carbonatite magma}

\section{differentiation}

Magnesium isotope fractionation during silicate-carbonatite liquid immiscibility predicts isotopically light original carbonatite melts at Oldoinyo Lengai. However, natrocarbonatite samples have positive $\delta^{26} \mathrm{Mg}$ values (Fig. 4), which requires a change of $\mathrm{Mg}$ isotopes of carbonatite melts subsequent to liquid immiscibility. Below, we explore the possible processes responsible for such a change.

One possible process is surface alteration, which can potentially fractionate $\mathrm{Mg}$ isotopes. The direction of $\mathrm{Mg}$ isotope fractionation during carbonate weathering has been investigated in previous studies on groundwater controlled by dedolomitization reactions and runoff waters draining carbonate bedrocks, which suggested little fractionation between dolomite and water (Jacobson et al., 2010) or the retention of 
light $\mathrm{Mg}$ isotopes in carbonates (Tipper et al., 2006, 2008; Brenot et al., 2008). Hence, the heavy $\mathrm{Mg}$ isotopic compositions of natrocarbonatites cannot be attributed to alteration of samples.

Another process that can also be ruled out is crustal contamination. Due to their low viscosity, carbonatite melts ascend very rapidly and, thus, crustal assimilation during carbonatite volcanism is generally limited. Moreover, assimilation of siliceous sedimentary rocks with heavy $\mathrm{Mg}$ isotopes $\left(\delta^{26} \mathrm{Mg}\right.$ up to $+0.92 \%$, Li et al., 2010) may increase the $\delta^{26} \mathrm{Mg}$ values of carbonatite melts. However, such a process conflicts with the very low $\mathrm{SiO}_{2}$ content $(<0.5 \mathrm{wt} \%$, Table 3) and mantle-like radiogenic and stable isotope characteristics (Keller and Hoefs, 1995; Bell and Tilton, 2001; Halama et al., 2007) of natrocarbonatites.

Diffusion-driven $\mathrm{Mg}$ isotope fractionation between ascending carbonate melts and wall rocks is also unlikely to produce the variable and heavy $\mathrm{Mg}$ isotopic compositions of natrocarbonatites at Lengai. First, diffusion of isotopes in melts is much faster than that in solids. Therefore, $\mathrm{Mg}$ isotopic heterogeneity in melts caused by diffusion will be eliminated quickly, producing isotopically homogeneous carbonatites. Second, light isotopes diffuse faster than heavy ones (e.g., Richter et al., 2008) and, hence, possible diffusion of $\mathrm{Mg}$ from wall rocks into the low- $\mathrm{Mg}$ natrocarbonatite melts (natrocarbonatites have $\mathrm{MgO}$ contents $<0.5 \mathrm{wt} \%$, Fig. 4) during magma ascent will result in light $\mathrm{Mg}$ isotopes in natrocarbonatites. This is opposite to the positive $\delta^{26} \mathrm{Mg}$ values of natrocarbonatites (Fig. 4).

Carbonatite magma differentiation is another process that may be responsible for 
341 the variable and positive $\delta^{26} \mathrm{Mg}$ values of natrocarbonatites. Fractional crystallization

342 of nyerereite $\left(\mathrm{Na}_{2} \mathrm{Ca}\left[\mathrm{CO}_{3}\right]_{2}\right)$ and gregoryite $\left(\left[\mathrm{Na}, \mathrm{Ca}_{x}, \mathrm{~K}\right]_{2-x} \mathrm{CO}_{3}\right)$ occurred during the 343 carbonatite magma differentiation at Oldoinyo Lengai (Peterson, 1990; Gittins and 344 Jago, 1998; Mattsson and Caricchi, 2009). Both of these two minerals are enriched 345 in alkali and alkaline earth metals. The trends of increasing $\delta^{26} \mathrm{Mg}$ values with 346 decreasing $\mathrm{CaO}+\mathrm{SrO}+\mathrm{BaO}$ and $\mathrm{Na}_{2} \mathrm{O}+\mathrm{K}_{2} \mathrm{O}$ contents in natrocarbonatites (Fig. 5) suggest that light $\mathrm{Mg}$ isotopes preferentially entered into fractionated nyerereite and 348 gregoryite. Therefore, fractional crystallization of nyerereite and gregoryite may 349 account for the observed $\mathrm{Mg}$ isotopic variations $\left(\delta^{26} \mathrm{Mg}\right.$ of +0.13 to $+0.37 \%$ ) in natrocarbonatites. The potential processes that drove $\mathrm{Mg}$ isotopic shift from the positive $\delta^{26} \mathrm{Mg}$ values ( $\geq+0.13 \%$ ) of natrocarbonatites (Fig. 4) remain to be defined.

\section{Conclusions} carbonated combeite-wollastonite-melilite nephelinites of the 2007-2008 activity, have $\delta^{26} \mathrm{Mg}$ values (from -0.25 to $-0.10 \%$ ) clustered around the mantle value. By contrast, combeite-wollastonite nephelinites from the unit Lengai II B, which 
363

evolved from the silicate melts that were presumably generated by liquid immiscibility, have high $\delta^{26} \mathrm{Mg}$ values of -0.06 to $+0.09 \%$. Such a difference suggests significant $\mathrm{Mg}$ isotope fractionation during liquid immiscibility and implies isotopically light original carbonatite melts at Lengai. However, natrocarbonatites have positive $\delta^{26} \mathrm{Mg}$ values from +0.13 to $+0.37 \%$. The negative correlations between $\delta^{26} \mathrm{Mg}$ values and $\mathrm{CaO}+\mathrm{SrO}+\mathrm{BaO}$ and $\mathrm{Na}_{2} \mathrm{O}+\mathrm{K}_{2} \mathrm{O}$ contents suggest significant $\mathrm{Mg}$ isotope fractionation due to fractional crystallization of nyerereite and grogoryite, with heavy $\mathrm{Mg}$ isotopes enriched in the residual melts relative to fractionated carbonate minerals.

The different behaviour of $\mathrm{Mg}$ isotopes between silicate magmatism and carbonatite magmatism promises different applications. Previous studies indicate limited Mg isotope fractionation during silicate magma differentiation and, hence, Mg isotopic compositions of basalts and granites can be used to constrain those of their mantle or crustal sources (Teng et al., 2007, 2010; Shen et al., 2009; Bourdon et al., 2010; Li et al., 2010). This study suggests, for the first time, that significant Mg isotope fractionation may occur during both silicate-carbonatite liquid immiscibility and fractional crystallization of carbonatite magmas. Consequently, Mg isotopic compositions of carbonatites may potentially be used to trace processes (i.e., liquid immiscibility and fractional crystallization) relevant to carbonatite petrogenesis. Nevertheless, $\mathrm{Mg}$ isotopic data of carbonatites are still very limited. In order to further investigate the magnitude and mechanism of $\mathrm{Mg}$ isotope fractionation during carbonatite magmatism and its applications, more comprehensive studies on 
385

386

387

388

389

390

391

392

393

394

395

396

397

398

399

400

401

402

403

404

405

406

carbonatite samples from different localities and of different genesis and evolution are needed.

\section{Acknowledgments}

We thank Shan Ke, Shui-Jiong Wang and Hai-Ou Gu for help in the lab and Wei Yang for discussions. The constructive comments from Paul Tomascak and two anonymous reviewers and efficient handling from Derek Vance are greatly appreciated. This work is financially supported by the National Natural Science Foundation of China (41573002) to WYL and by the National Science Foundation (EAR-0838227, EAR-1056713 and EAR-1340160) to FZT.

\section{References}

Bell, K., Simonetti, A., 1996. Carbonatite magmatism and plume activity: implications from the $\mathrm{Nd}, \mathrm{Pb}$ and $\mathrm{Sr}$ isotope systematics of Oldoinyo Lengai. J. Petrol. 37, 1321-1339.

Bell, K., Tilton, G.R., 2001. Nd, Pb and Sr isotopic compositions of East African carbonatites: evidence for mantle mixing and plume inhomogeneity. J. Petrol. 42, 1927-1945.

Bigeleisen, J., 1965. Chemistry of isotopes. Science 147, 463-471.

Bourdon, B., Tipper, E.T., Fitoussi, C., Stracke, A., 2010. Chondritic Mg isotope composition of the Earth. Geochim. Cosmochim. Acta 74, 5069-5083. 
Bouvier, A., Wadhwa, M., Simon, S.B., Grossman, L., 2013. Magnesium isotopic fractionation in chondrules from the Murchison and Murray CM2 carbonaceous chondrites. Meteorit. Planet. Sci. 48, 339-353.

Brenot, A., Cloquet, C., Vigier, N., Carignan, J., France-Lanord, C., 2008. Magnesium isotope systematics of the lithologically varied Moselle river basin, France. Geochim. Cosmochim. Acta 72, 5070-5089.

Church, A.A., Jones, A.P., 1995. Silicate-carbonate immiscibility at Oldoinyo Lengai. J. Petrol. 36, 869-889.

Dauphas, N., Teng, F.-Z., Arndt, N.T., 2010. Magnesium and iron isotopes in $2.7 \mathrm{Ga}$ Alexo komatiites: mantle signatures, no evidence for Soret diffusion, and identification of diffusive transport in zoned olivine. Geochim. Cosmochim. Acta 74, 3274-3291.

Dawson, J.B., 1998. Peralkaline nephelinite-natrocarbonatite relationships at Oldoinyo Lengai, Tanzania. J. Petrol. 39, 2077-2094.

Dawson, J.B., Smith, J.V., Jones, A.P., 1985. A comparative study of bulk rock and mineral chemistry of olivine melilitites and associated rocks from East and South Africa. Neues. Jahrb. Mineral. Abh. 152, 143-175.

Foster, G.L., Pogge von Strandmann, P.A.E., Rae, J.W.B., 2010. Boron and magnesium isotopic composition of seawater. Geochem. Geophys. Geosyst. Q08015, doi:10.1029/2010GC003201.

Gittins, J., Jago, B.C., 1998. Differentiation of natrocarbonatite magma at Oldoinyo Lengai volcano, Tanzania. Mineral. Mag. 62, 759-768. 
Halama, R., McDonough, W.F., Rudnick, R.L., Keller, J., Klaudius, J., 2007. The Li isotopic composition of Oldoinyo Lengai: nature of the mantle sources and lack of isotopic fractionation during carbonatite petrogenesis. Earth Planet. Sci. Lett. $254,77-89$.

Handler, M.R., Baker, J.A., Schiller, M., Bennett, V.C., Yaxley, G.M., 2009. Magnesium stable isotope composition of Earth's upper mantle. Earth Planet. Sci. Lett. 282, 306-313.

Henderson, G.S., Calas, G., Stebbins, J.F., 2006. The structure of silicate glasses and metls. Elements 2, 269-273.

Huang, F., Zhang, Z., Lundstrom, C.C., Zhi, X., 2011. Iron and magnesium isotopic compositions of peridotite xenoliths from Eastern China. Geochim. Cosmochim. Acta 75, 3318-3334.

Jacobson, A.D., Zhang, Z., Lundstrom, C., Huang, F., 2010. Behavior of Mg isotopes during dedolomitization in the Madison Aquifer, South Dakota. Earth Planet. Sci. Lett. 297, 446-452.

Johnson, C.M., Bell, K., Beard, B.L., Shultis, A.I., 2010. Iron isotope compositions of carbonatites record melt generation, crystallization, and late-stage volatile-transport processes. Miner. Petrol. 98, 91-110.

Jones, J.H., Walker, D., Picket, D.A., Murrel, M.T., Beate, P., 1995. Experimental investigations of the partitioning of $\mathrm{Nb}, \mathrm{Mo}, \mathrm{Ba}, \mathrm{Ce}, \mathrm{Pb}, \mathrm{Ra}, \mathrm{Th}, \mathrm{Pa}$ and $\mathrm{U}$ between immiscible carbonate and silicate liquids. Geochim. Cosmochim. Acta 59, 1307-1320. 
Keller, J., Hoefs, J., 1995. Stable isotope characteristics of recent natrocarbonatites from Oldoinyo Lengai. In: Bell, K., Keller, J. (Eds.), Carbonatite Volcanism: Oldoinyo Lengai and the Petrogenesis of Natrocarbonatite, Springer-Verlag, Berlin, pp. 113-123.

Keller, J., Spettel, B., 1995. The trace element composition and petrogenesis of natrocarbonatites. In: Bell, K., Keller, J. (Eds.), Carbonatite Volcanism: Oldoinyo Lengai and the Petrogenesis of Natrocarbonatite, Springer-Verlag, Berlin, pp. 70-86.

Keller, J., Zaitsev, A.N., Wiedenmann, D., 2006. Primary magmas at Oldoinyo Lengai: the role of olivine melilitites. Lithos 91, 150-172.

Keller, J., Klaudius, J., Kervyn, M., Ernst, G.G.J., Mattsson, H.B., 2010. Fundamental changes in the activity of the natrocarbonatite volcano Oldoinyo Lengai, Tanzania. I. New magma composition during the 2007-2008 explosive eruptions. Bull. Volcanol. 72, 893-912.

Kjarsgaard, B.A., Hamilton, D.L., Peterson, T.D., 1995. Peralkaline nephelinite/carbonatite liquid immiscibility: comparison of phase compositions in experiments and natural lavas from Oldoinyo Lengai. In: Bell, K., Keller, J. (Eds.), Carbonatite Volcanism: Oldoinyo Lengai and the Petrogenesis of Natrocarbonatite, Springer-Verlag, Berlin, pp. 163-190.

Klaudius, J., Keller, J., 2006. Peralkaline silicate lavas at Oldoinyo Lengai, Tanzania. Lithos 91, 173-190. 
Lai, Y.-J., Pogge von Strandmann, P.A.E., Dohmen, R., Takazawa, E., Elliott, T., 2015. The influence of melt infiltration on the $\mathrm{Li}$ and $\mathrm{Mg}$ isotopic composition of the Horoman Peridotite Massif. Geochim. Cosmochim. Acta 164, 318-332.

Li, W.-Y., Teng, F.-Z., Ke, S., Rudnick, R.L., Gao, S., Wu, F.-Y., Chappell, B.W., 2010. Heterogeneous magnesium isotopic composition of the upper continental crust. Geochim. Cosmochim. Acta 74, 6867-6884.

Ling, M.-X., Sedaghatpour, F., Teng, F.-Z., Hays, P.D., Strauss, J., Sun, W., 2011. Homogeneous magnesium isotopic composition of seawater: an excellent geostandard for $\mathrm{Mg}$ isotope analysis. Rapid Commun. Mass Spectrom. 25, $2828-2836$.

Ling, M.-X., Liu, Y.-L., Williams, I.S., Teng, F.-Z., Yang, X.-Y., Ding, X., Wei, G.-J., Xie, L.-H., Deng, W.-F., Sun, W.-D., 2013. Formation of the world's largest REE deposit through protracted fluxing of carbonatite by subduction-derived fluids. Sci. Rep. 3, 1776, doi: 10.1038/srep01776.

Macris, C.A., Young, E.D., Manning, C.E., 2013. Experimental determination of equilibrium magnesium isotope fractionation between spinel, forsterite, and magnesite from 600 to $800{ }^{\circ} \mathrm{C}$. Geochim. Cosmochim. Acta 118, 18-32.

Martin, L.H.J., Schmidt, M.W., Mattsson, H.B., Guenther, D., 2013. Element partitioning between immiscible carbonatite and silicate melts for dry and $\mathrm{H}_{2} \mathrm{O}$-bearing systems at 1-3GPa. J. Petrol. 54, 2301-2338.

Mattsson, H.B., 2012. Rapid magma ascent and short eruption durations in the Lake Natron-Engaruka monogenetic volcanic field (Tanzania): a case study of the 
olivine melilititic Pello Hill scoria cone. J. Volcanol. Geotherm. Res. 247-248, $16-25$.

Mattsson, H.B., Caricchi, L., 2009. Experimental constraints on the crystallization of natrocarbonatitic lava flows. Bull. Volcanol. 71, 1179-1193.

Mattsson, H.B., Nandedkar, R.H., Ulmer, P., 2013. Petrogenesis of the melilititic and nephelinitic rock suites in the Lake Natron-Engaruka monogenetic volcanic field, northern Tanzania. Lithos 179, 175-192.

Mitchell, R.H., 2009. Peralkaline nephelinite-natrocarbonatite immiscibility and carbonatite assimilation at Oldoinyo Lengai, Tanzania. Contrib. Mineral. Petrol. $158,589-598$.

Morogan, V., Martin, R.F., 1985. Mineralogy and partial melting of fenitized crustal xenoliths in the Oldoinyo Lengai carbonatite volcano, Tanzania. Am. Mineral. 70, 1114-1126.

Nielsen, T.F.D., Veksler, I.V., 2002. Is natrocarbonatite a cognate fluid condensate? Contrib. Mineral. Petrol. 142, 425-435.

Peterson, T.D., 1990. Petrology and genesis of natrocarbonatite. Contrib. Mineral. Petrol. 105, 143-155.

Peterson, T.D., Kjarsgaard, B.A., 1995. What are the parental magmas at Oldoinyo Lengai? In: Bell, K., Keller, J. (Eds.), Carbonatite Volcanism: Oldoinyo Lengai and the Petrogenesis of Natrocarbonatite, Springer-Verlag, Berlin, pp. 148-162. 
Pogge von Strandmann, P.A.E., Elliott, T., Marschall, H.R., Coath, C., Lai, Y.-J., Jeffcoate, A.B., Ionov, D.A., 2011. Variations of $\mathrm{Li}$ and $\mathrm{Mg}$ isotope ratios in bulk chondrites and mantle xenoliths. Geochim. Cosmochim. Acta 75, 5247-5268.

Richter, F.M., Watson, E.B., Mendybaev, R.A., Teng, F.-Z., Janney, P.E., 2008. Magnesium isotope fractionation in silicate melts by chemical and thermal diffusion. Geochim. Cosmochim. Acta 72, 206-220.

Schauble, E.A., 2011. First-principles estimates of equilibrium magnesium isotope fractionation in silicate, oxide, carbonate and hexaaquamagnesium(2+) crystals. Geochim. Cosmochim. Acta 75, 844-869.

Schiller, M., Handler, M.R., Baker, J.A., 2010. High-precision Mg isotopic systematics of bulk chondrites. Earth Planet. Sci. Lett. 297, 165-173.

Sekisova, V.S., Sharygin, V.V., Zaitsev, A.N., Strekopytov, S., 2015. Liquid immiscibility during crystallization of forsterite-phlogopite ijolites at Oldoinyo Lengai Volcano, Tanzania: study of melt inclusions. Rus. Geol. Geophys. 56, $1717-1737$.

Shen, B., Jacobsen, B., Lee, C.-T.A., Yin, Q.-Z., Morton, D.M., 2009. The Mg isotopic systematics of granitoids in continental arcs and implications for the role of chemical weathering in crust formation. Proc. Natl. Acad. Sci. USA. 106, 20652-20657.

Simonetti, A., Bell, K., Shrady, C., 1997. Trace- and rare-earth-element geochemistry of the June 1993 natrocarbonatite lavas, Oldoinyo Lengai 

Geotherm. Res. 75, 89-106.

Sun, J., Fang, N., Li, S., Chen, Y., Zhu, X., 2012. Magnesium isotopic constraints on the genesis of Bayan Obo ore deposit. Acta Petrol. Sinica 28, 2890-2902.

Teng, F.-Z., Wadhwa, M., Helz, R.T., 2007. Investigation of magnesium isotope

Teng, F.-Z., Li, W.-Y., Ke, S., Marty, B., Dauphas, N., Huang, S., Wu, F.-Y., Pourmand, A., 2010. Magnesium isotopic composition of the Earth and chondrites. Geochim. Cosmochim. Acta 74, 4150-4166.

Teng, F.-Z., Yang, W., 2014. Comparison of factors affecting the accuracy of high-precision magnesium isotope analysis by multi-collector inductively coupled plasma mass spectrometry. Rapid Commun. Mass Spectrom. 28, 19-24.

Teng, F.-Z., Li, W.-Y., Ke, S., Yang, W., Liu, S.-A., Sedaghatpour, F., Wang, S.-J., Huang, K.-J., Hu, Y., Ling, M.-X., Xiao, Y., Liu, X.-M., Li, X.-W., Gu, H.-O., Sio, C.K., Wallace, D.A., Su, B.-X., Zhao, L., Chamberlin, J., Harrington, M., Brewer, A., 2015. Magnesium isotopic compositions of international geological reference materials. Geostand. Geoanal. Res. 39, 329-339.

Tipper, E.T., Galy, A., Gaillardet, J., Bickle, M.J., Elderfield, H., Carder, E.A., 2006. The magnesium isotope budget of the modern ocean: constraints from riverine magnesium isotope ratios. Earth Planet. Sci. Lett. 250, 241-253. 
Tipper, E.T., Galy, A., Bickle, M.J., 2008. Calcium and magnesium isotope systematics in rivers draining the Himalaya-Tibetan-Plateau region: lithological or fractionation control? Geochim. Cosmochim. Acta 72, 1057-1075.

Twyman, J.D., Gittins, J., 1987. Alkalic carbonatite magmas: parental or derivative? In: Fitton, J.G., Upton, B.G.J. (Eds.), Alkaline Igneous Rocks, Geol. Soc. Spec. Publ. 30, 85-94.

Vuilleumier, R., Seitsonen, A., Sator, N., Guillot, B., 2014. Structure, equation of state and transport properties of molten calcium carbonate $\left(\mathrm{CaCO}_{3}\right)$ by atomistic simulations. Geochim. Cosmochim. Acta 141, 547-566.

Wang, G., Lin, Y., Liang, X., Liu, Y., Xie, L., Yang, Y., Tu, X., 2011. Separation of magnesium from meteorites and terrestrial silicate rocks for high-precision isotopic analysis using multiple collector-inductively coupled plasma-mass spectrometry. J. Anal. At. Spectrom. 26, 1878-1886.

Wiedenmann, D., Keller, J., Zaitsev, A.N., 2010. Melilite-group minerals at Oldoinyo Lengai, Tanzania. Lithos 118, 112-118.

Xiao, Y., Teng, F.-Z., Zhang, H.-F., Yang, W., 2013. Large magnesium isotope fractionation in peridotite xenoliths from eastern North China craton: product of melt-rock interaction. Geochim. Cosmochim. Acta 115, 241-261.

Yang, W., Teng, F.-Z., Zhang, H.-F., 2009. Chondritic magnesium isotopic composition of the terrestrial mantle: a case study of peridotite xenoliths from the North China craton. Earth Planet. Sci. Lett. 288, 475-482. 
577 Zaitsev, A.N., Keller, J., 2006. Mineralogical and chemical transformation of 578 Oldoinyo Lengai natrocarbonatites, Tanzania. Lithos 91, 191-207. 579 
581 Magnesium isotopic compositions of synthetic solutions and reference materials.

\begin{tabular}{|c|c|c|c|c|}
\hline Standard & $\delta^{26} \mathrm{Mg}(\% 0)$ & $2 \mathrm{SD}^{\mathrm{a}}$ & $\delta^{25} \mathrm{Mg}(\%)$ & $2 \mathrm{SD}$ \\
\hline IL-Mg-1 ${ }^{\mathrm{b}}$ & -0.04 & 0.07 & -0.04 & 0.04 \\
\hline Replicate $^{c}$ & -0.04 & 0.07 & -0.03 & 0.03 \\
\hline Replicate & -0.01 & 0.07 & 0.00 & 0.05 \\
\hline Replicate & -0.03 & 0.10 & -0.02 & 0.05 \\
\hline The expected value & 0.00 & 0.07 & 0.00 & 0.05 \\
\hline $\operatorname{Carb}^{\mathrm{d}}$ & -0.03 & 0.04 & -0.01 & 0.04 \\
\hline Replicate & -0.05 & 0.08 & +0.01 & 0.04 \\
\hline Replicate & -0.03 & 0.08 & -0.04 & 0.05 \\
\hline Replicate & -0.02 & 0.08 & -0.04 & 0.05 \\
\hline The expected value & 0.00 & 0.07 & 0.00 & 0.05 \\
\hline Seawater & -0.84 & 0.07 & -0.42 & 0.04 \\
\hline Replicate & -0.86 & 0.08 & -0.42 & 0.05 \\
\hline Foster et al. (2010) & -0.82 & 0.05 & -0.43 & 0.05 \\
\hline Ling et al. (2011) & -0.83 & 0.09 & -0.43 & 0.06 \\
\hline Allende chondrite & -0.34 & 0.06 & -0.19 & 0.04 \\
\hline Replicate & -0.27 & 0.12 & -0.16 & 0.06 \\
\hline Schiller et al. (2010) & -0.35 & 0.13 & -0.19 & 0.07 \\
\hline Pogge von Strandmann et al. (2011) & -0.36 & 0.06 & -0.19 & 0.05 \\
\hline Wang et al. (2011) & -0.30 & 0.17 & -0.17 & 0.07 \\
\hline Bouvier et al. (2013) & -0.29 & 0.05 & -0.16 & 0.03 \\
\hline KH-olivine ${ }^{\mathrm{e}}$ & -0.33 & 0.06 & -0.18 & 0.05 \\
\hline Replicate & -0.32 & 0.07 & -0.18 & 0.05 \\
\hline Replicate & -0.30 & 0.08 & -0.13 & 0.04 \\
\hline Yang et al. (2009) & -0.32 & 0.10 & -0.19 & 0.05 \\
\hline Li et al. (2010) & -0.31 & 0.06 & -0.16 & 0.05 \\
\hline Teng et al. (2015) & -0.27 & 0.07 & -0.14 & 0.05 \\
\hline
\end{tabular}

a $2 \mathrm{SD}=$ two times the standard deviation of the population of $\mathrm{n}(\mathrm{n}>20)$ repeat measurements

583 of the standards during an analytical session.

$584{ }^{\mathrm{b}} \mathrm{IL}-\mathrm{Mg}-1$ is a synthetic solution with concentration ratios of Mg:Fe:Al:Ca:Na:K:Ti = $585 \quad 1: 1: 1: 1: 1: 1: 0.1$

$586{ }^{\mathrm{c}}$ Replicate $=$ repeat column chemistry and measurements of different aliquots of a stock

587 solution.

$588 \quad{ }^{\mathrm{d}}$ Carb is a synthetic solution with concentration ratios of $\mathrm{Ca}: \mathrm{Mg}=100: 1$.

$589{ }^{\mathrm{e}} \mathrm{KH}$-olivine is an in-house reference solution made from the Kilbourne Hole olivine. 
591 Magnesium isotopic compositions and selected geochemical parameters of

592 peralkaline silicate rocks from Oldoinyo Lengai.

\begin{tabular}{|c|c|c|c|c|c|c|c|}
\hline Sample ID & $\delta^{26} \mathrm{Mg}(\%)$ & $2 \mathrm{SD}^{\mathrm{a}}$ & $\delta^{25} \mathrm{Mg}(\% \mathrm{o})$ & 2SD & $\mathrm{SiO}_{2}(\mathrm{wt} \%)^{\mathrm{b}}$ & $\mathrm{MgO}(\mathrm{wt} \%)^{\mathrm{b}}$ & $\mathrm{Mg} \#^{\mathrm{b}}$ \\
\hline \multicolumn{8}{|c|}{ Olivine melilitites from the vicinity of Oldoinyo Lengai } \\
\hline OL198 & -0.30 & 0.08 & -0.15 & 0.05 & 36.48 & 13.78 & 68.7 \\
\hline OL343 & -0.26 & 0.08 & -0.12 & 0.05 & 36.35 & 15.04 & 69.8 \\
\hline OL352 & -0.26 & 0.08 & -0.14 & 0.05 & 36.38 & 14.92 & 70.3 \\
\hline OL12/2K & -0.27 & 0.08 & -0.15 & 0.05 & 34.07 & 9.80 & 58.7 \\
\hline \multicolumn{8}{|c|}{ Phonolites from the unit Lengai I } \\
\hline OL440 & -0.10 & 0.07 & -0.05 & 0.06 & 47.94 & 0.81 & 20.5 \\
\hline OL442 & -0.11 & 0.07 & -0.05 & 0.08 & 51.07 & 0.85 & 25.2 \\
\hline OL450 & -0.08 & 0.11 & -0.03 & 0.06 & 52.91 & 0.74 & 22.3 \\
\hline Repeat $^{\mathrm{c}}$ & -0.15 & 0.07 & -0.07 & 0.06 & & & \\
\hline OL503 & -0.13 & 0.11 & -0.05 & 0.06 & 49.34 & 1.28 & 27.6 \\
\hline Repeat & -0.17 & 0.07 & -0.06 & 0.06 & & & \\
\hline OL822 & -0.26 & 0.08 & -0.15 & 0.05 & 50.01 & 0.83 & 23.6 \\
\hline Repeat & -0.23 & 0.09 & -0.12 & 0.05 & & & \\
\hline \multicolumn{8}{|c|}{ Combeite-wollastonite nephelinites (CWNs) from the unit Lengai II A } \\
\hline OL247 & -0.17 & 0.10 & -0.10 & 0.07 & 41.79 & 1.95 & 30.7 \\
\hline Repeat & -0.10 & 0.07 & -0.04 & 0.06 & & & \\
\hline OL803 & -0.15 & 0.09 & -0.07 & 0.07 & 46.32 & 1.18 & 24.6 \\
\hline Repeat & -0.10 & 0.10 & -0.05 & 0.07 & & & \\
\hline \multicolumn{8}{|c|}{ Combeite-wollastonite nephelinites (CWNs) from the unit Lengai II B } \\
\hline OL624 & -0.04 & 0.09 & -0.03 & 0.07 & 43.40 & 1.28 & 20.6 \\
\hline Repeat & -0.08 & 0.06 & -0.05 & 0.06 & & & \\
\hline OL788 & +0.11 & 0.09 & +0.08 & 0.07 & 44.58 & 0.93 & 17.6 \\
\hline Repeat & +0.03 & 0.11 & +0.03 & 0.06 & & & \\
\hline OL804 & +0.08 & 0.08 & +0.02 & 0.05 & 45.51 & 0.64 & 12.1 \\
\hline Repeat & +0.10 & 0.08 & +0.03 & 0.05 & & & \\
\hline \multicolumn{8}{|c|}{ Carbonated combeite-wollastonite-melilite nephelinites (carbCWMNs) of the 2007-2008 activity } \\
\hline OL835-1 & -0.17 & 0.07 & -0.09 & 0.06 & 28.54 & 1.35 & 30.3 \\
\hline OL836 & -0.17 & 0.09 & -0.09 & 0.07 & 29.57 & 1.87 & 36.5 \\
\hline Repeat & -0.16 & 0.10 & -0.10 & 0.07 & & & \\
\hline OL837 & -0.15 & 0.09 & -0.07 & 0.07 & 25.99 & 1.63 & 37.0 \\
\hline
\end{tabular}

${ }^{\text {a }} 2 \mathrm{SD}=$ two times the standard deviation of the population of $n(n>20)$ repeat measurements

594 of the standards during an analytical session.

$595{ }^{\mathrm{b}}$ Data are from Keller et al. $(2006,2010)$ and Klaudius and Keller (2006); Mg\# = molar $596 \mathrm{Mg} /\left(\mathrm{Mg}+\mathrm{Fe}^{2+}\right) \times 100$.

$597 \quad{ }^{\mathrm{c}}$ Repeat $=$ repeat dissolution and column chemistry of individual samples. 
599 Magnesium isotopic compositions and selected geochemical parameters of natrocarbonatites from Oldoinyo Lengai.

\begin{tabular}{|c|c|c|c|c|c|c|c|c|c|c|c|c|c|c|c|}
\hline Sample ID & $\begin{array}{c}\text { Column } \\
\text { procedures }^{\mathrm{a}}\end{array}$ & $\begin{array}{c}\delta^{26} \mathrm{Mg} \\
(\%)\end{array}$ & $2 \mathrm{SD}^{\mathrm{b}}$ & $\begin{array}{c}\delta^{25} \mathrm{Mg} \\
(\% 0)\end{array}$ & $2 \mathrm{SD}$ & $\begin{array}{c}\mathrm{SiO}_{2} \\
(\mathrm{wt} \%)^{\mathrm{c}}\end{array}$ & $\begin{array}{c}\mathrm{MgO} \\
(\mathrm{wt} \%)^{\mathrm{c}}\end{array}$ & $\begin{array}{l}\mathrm{Na}_{2} \mathrm{O} \\
(\mathrm{wt} \%)^{\mathrm{c}}\end{array}$ & $\begin{array}{c}\mathrm{K}_{2} \mathrm{O} \\
(\mathrm{wt} \%)^{\mathrm{c}}\end{array}$ & $\begin{array}{c}\mathrm{CaO} \\
(\mathrm{wt} \%)^{\mathrm{c}}\end{array}$ & $\begin{array}{c}\mathrm{SrO} \\
(\mathrm{wt} \%)^{\mathrm{c}}\end{array}$ & $\begin{array}{c}\mathrm{BaO} \\
(\mathrm{wt} \%)^{\mathrm{c}}\end{array}$ & $\begin{array}{l}\delta^{18} \mathrm{O} \\
(\%)^{d}\end{array}$ & $\begin{array}{l}\delta^{13} \mathrm{C} \\
(\%))^{\mathrm{d}}\end{array}$ & $\begin{array}{l}\delta^{7} \mathrm{Li} \\
(\%)^{\mathrm{d}}\end{array}$ \\
\hline OL2 & $\mathrm{Mg} \times 4$ & +0.29 & 0.07 & +0.14 & 0.05 & 0.21 & 0.42 & 30.41 & 6.66 & 12.08 & 1.13 & 1.50 & +9.2 & -6.9 & +3.6 \\
\hline Replicate $^{\mathrm{e}}$ & $\mathrm{Mg} \times 5$ & +0.32 & 0.07 & +0.21 & 0.08 & & & & & & & & & & \\
\hline Repeat $^{\mathrm{f}}$ & $\mathrm{Mg} \times 2+\mathrm{Ca}$ & +0.35 & 0.10 & +0.23 & 0.08 & & & & & & & & & & \\
\hline Replicate & $\mathrm{Mg} \times 3+\mathrm{Ca}$ & +0.29 & 0.08 & +0.10 & 0.05 & & & & & & & & & & \\
\hline OL7 & $\mathrm{Mg} \times 4$ & +0.36 & 0.07 & +0.20 & 0.05 & 0.10 & 0.47 & 30.85 & 6.67 & 11.71 & 1.10 & 1.60 & +9.3 & -7.0 & +3.3 \\
\hline Replicate & $\mathrm{Mg} \times 5$ & +0.38 & 0.07 & +0.23 & 0.08 & & & & & & & & & & \\
\hline Repeat & $\mathrm{Mg} \times 2+\mathrm{Ca}$ & +0.37 & 0.10 & +0.19 & 0.07 & & & & & & & & & & \\
\hline OL123 & $\mathrm{Mg} \times 4$ & +0.12 & 0.06 & +0.07 & 0.05 & 0.44 & 0.42 & 31.92 & 7.46 & 15.97 & 1.41 & 1.26 & +8.6 & -7.0 & +4.8 \\
\hline Repeat & $\mathrm{Mg} \times 2+\mathrm{Ca}$ & +0.23 & 0.07 & +0.10 & 0.08 & & & & & & & & & & \\
\hline Replicate & $\mathrm{Mg} \times 3+\mathrm{Ca}$ & +0.22 & 0.10 & +0.05 & 0.07 & & & & & & & & & & \\
\hline OL148 & $\mathrm{Mg} \times 4$ & +0.18 & 0.07 & +0.10 & 0.05 & & 0.44 & 32.57 & 8.45 & 14.53 & 1.35 & 1.68 & +7.4 & -7.0 & +4.6 \\
\hline Repeat & $\mathrm{Mg} \times 2+\mathrm{Ca}$ & +0.11 & 0.07 & +0.10 & 0.08 & & & & & & & & & & \\
\hline Replicate & $\mathrm{Mg} \times 3+\mathrm{Ca}$ & +0.20 & 0.10 & +0.06 & 0.07 & & & & & & & & & & \\
\hline OL259 & $\mathrm{Mg} \times 4$ & +0.12 & 0.07 & +0.10 & 0.05 & 0.23 & 0.43 & 32.74 & 8.30 & 15.11 & 1.46 & 1.54 & +7.4 & -6.9 & +5.0 \\
\hline Replicate & $\mathrm{Mg} \times 5$ & +0.15 & 0.08 & +0.04 & 0.05 & & & & & & & & & & \\
\hline Repeat & $\mathrm{Mg} \times 2+\mathrm{Ca}$ & +0.12 & 0.10 & +0.04 & 0.08 & & & & & & & & & & \\
\hline
\end{tabular}

$601 \quad{ }^{b} 2 S D=$ two times the standard deviation of the population of $n(n>20)$ repeat measurements of the standards during an analytical session.

${ }^{\mathrm{c}}$ Data are from Simonetti et al. (1997).

$603 \quad{ }^{\mathrm{d}}$ Data are from Halama et al. (2007).

$604 \quad{ }^{\mathrm{e}}$ Replicate $=$ repeat column chemistry and measurement of different aliquots of a stock solution.

${ }^{\mathrm{f}}$ Repeat $=$ repeat dissolution and column chemistry of individual samples. 
607

608

609

610

611

612

613

614

615

616

617

618

619

620

621

622

623

624

625

626

627 Fig. 4. $\delta^{26} \mathrm{Mg} \quad(\%) \quad$ vs. $\mathrm{MgO} \quad(\mathrm{wt} \%)$ for peralkaline silicate rocks and

Fig. 1. Flow chart illustrating the petrogenesis of peralkaline silicate rocks and natrocarbonatites at Oldoinyo Lengai. The magmatic evolution at Lengai includes three main processes: (1) peralkaline silicate magma differentiation, silicate-carbonatite liquid immiscibility, and (3) carbonatite magma differentiation. The parental melts of the Lengai volcano and how the phonolitic and nephelinitic melts evolved from the parental melts are unknown and labeled with question marks. See text for details and related references.

Fig. 2. $\delta^{26} \mathrm{Mg}(\%)$ vs. $\mathrm{CaO} / \mathrm{MgO}(\mathrm{wt} / \mathrm{wt}$ ) for natrocarbonatites processed through different column procedures (see text for details). The error bar indicates the maximum external precision of $\pm 0.10 \%$ (2SD) on $\delta^{26} \mathrm{Mg}$ during analytical sessions of this study. Data are reported in Table 3.

Fig. 3. Magnesium three-isotope diagram of all samples analyzed in this study. Repeated measurements of individual samples are shown as individual points. The solid line represents the isotopic mass-dependent fractionation line with a slope of 0.518. Error bars represent the 2SD uncertainties of individual samples. Data are reported in Tables 2 and 3. 
628

629

630

631

632

633

634

635

636

637

638

639

640

641

642

643

natrocarbonatites from Oldoinyo Lengai. The gray band and horizontal solid line represent the average $\delta^{26} \mathrm{Mg}$ value of the pristine mantle $(-0.25 \pm 0.07 \%$, 2SD, Teng et al., 2010). Three arrows represent (1) peralkaline silicate magma differentiation, (2) silicate-carbonatite liquid immiscibility, and (3) carbonatite magma differentiation, respectively. The dashed diamond represents the inferred "original carbonatite melts" at Lengai, whose $\delta^{26} \mathrm{Mg}$ values and $\mathrm{MgO}$ contents are unknown and shown schematically in the diagram. Error bars represent the maximum external precision of $\pm 0.10 \%$ o (2SD) on $\delta^{26} \mathrm{Mg}$ during analytical sessions of this study. Data are reported in Tables 2 and 3 .

Fig. 5. $\delta^{26} \mathrm{Mg}(\%)$ vs. (a) $\mathrm{CaO}+\mathrm{SrO}+\mathrm{BaO}\left(\mathrm{wt} \%\right.$ ) and (b) $\mathrm{Na}_{2} \mathrm{O}+\mathrm{K}_{2} \mathrm{O}$ (wt $\%$ ) for natrocarbonatites from Oldoinyo Lengai. The red lines represent linear regressions and the gray arrows represent the assumed general trends for fractional crystallization of nyerereite and gregoryite. Error bars represent the 2SD uncertainties of the population of $n(=3$ or 4$)$ repeat measurements of individual natrocarbonatite samples. Data are reported in Table 3. 


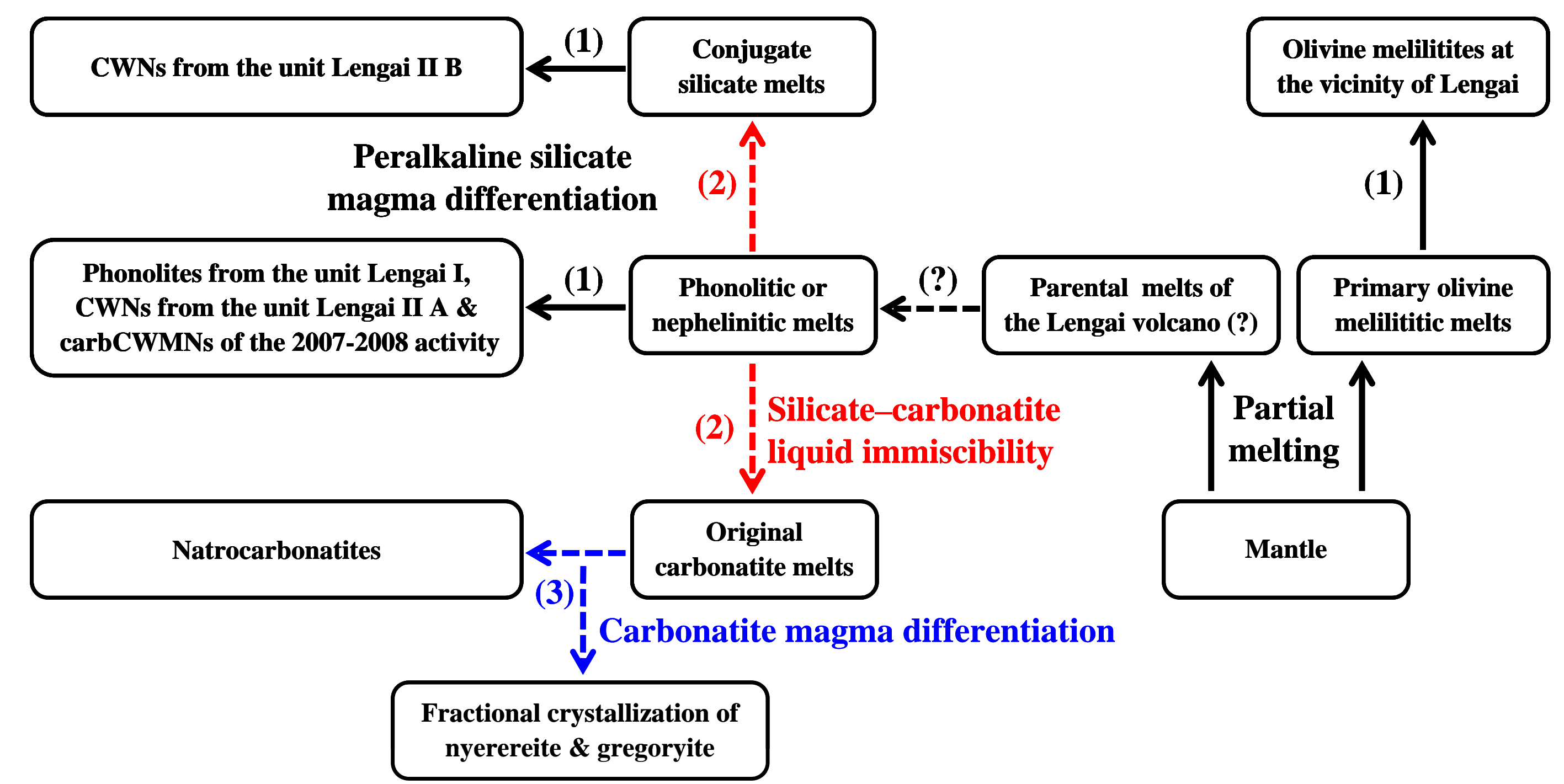

Fig. 1 


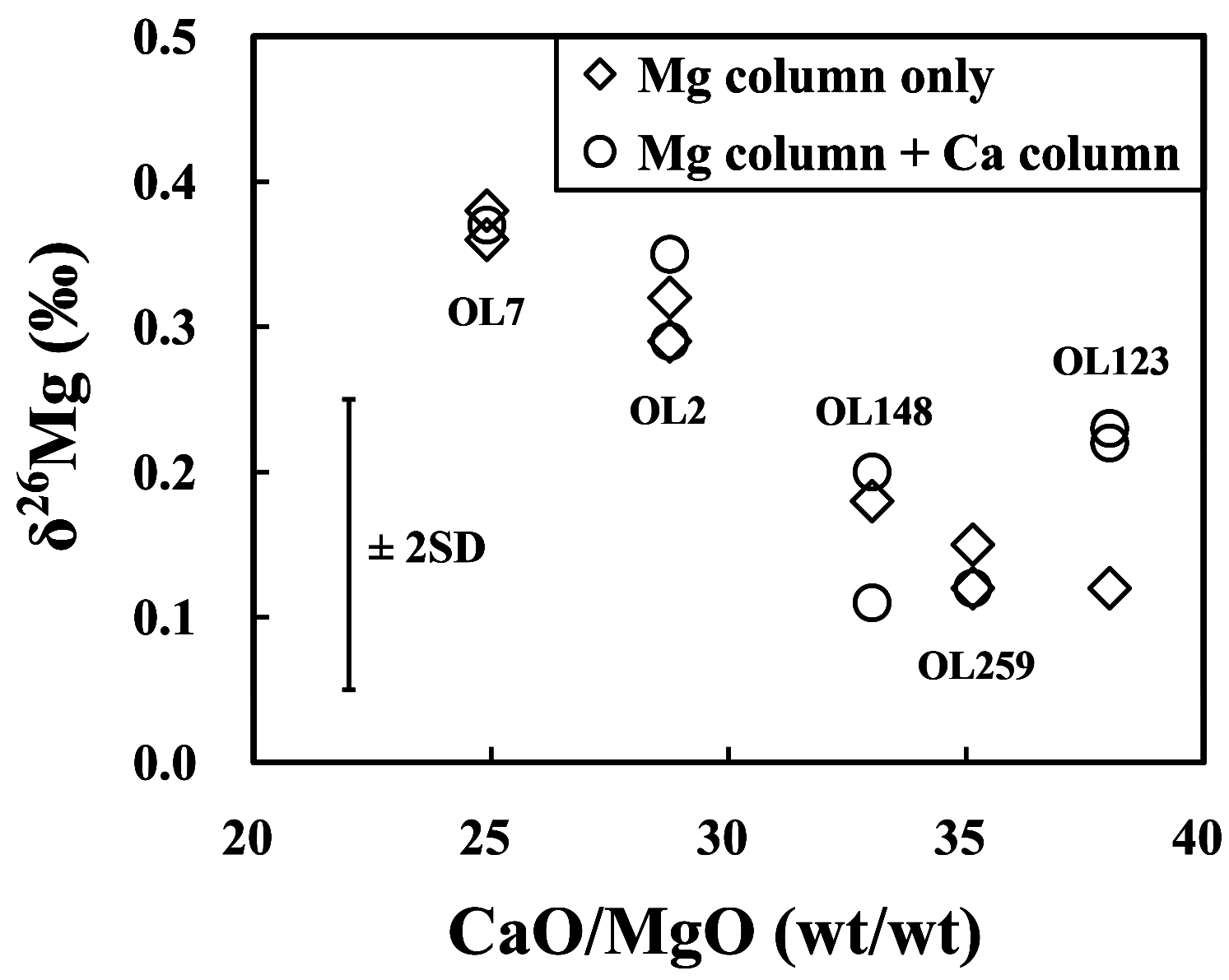

Fig. 2 


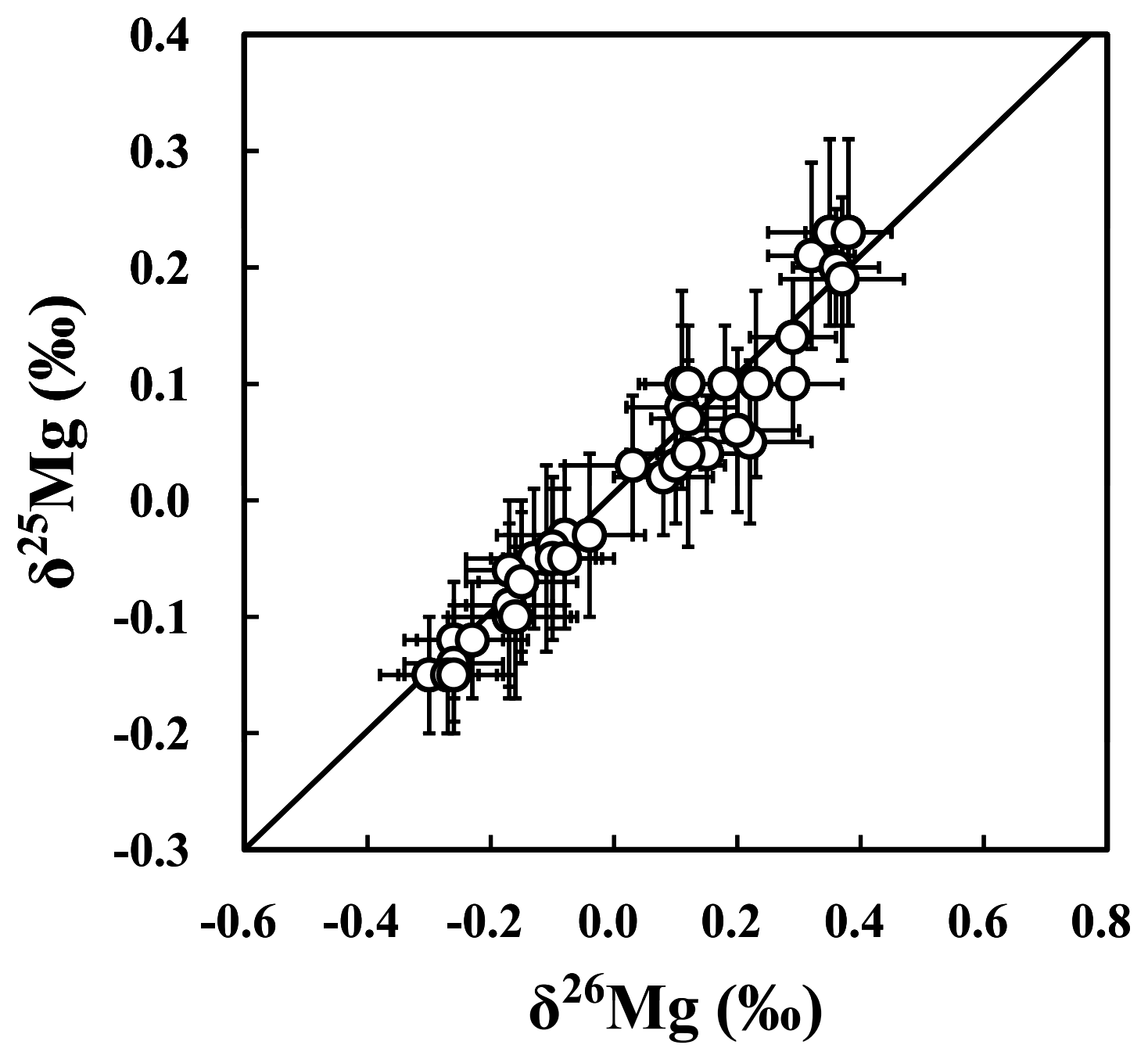

Fig. 3 


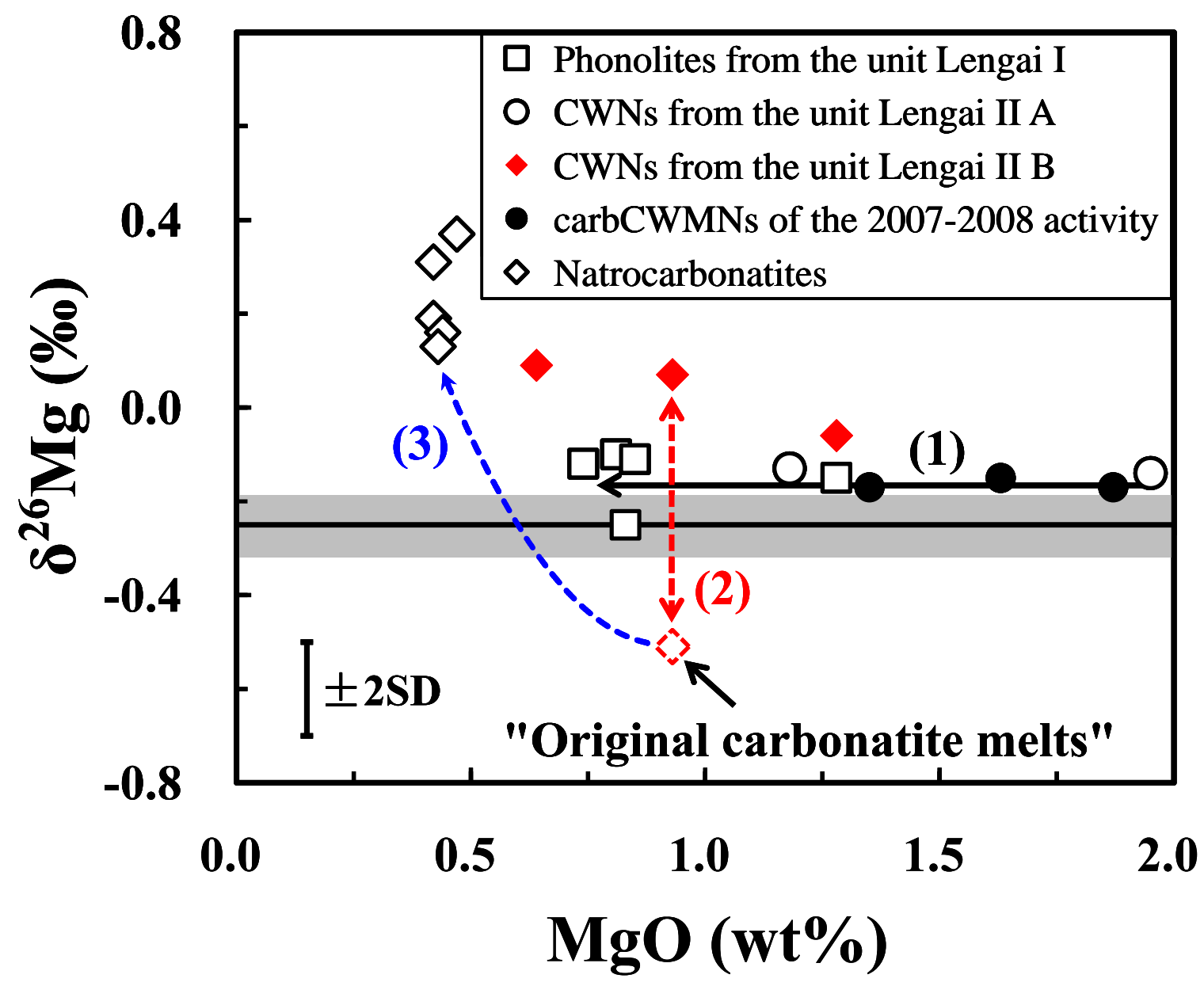

Fig. 4 


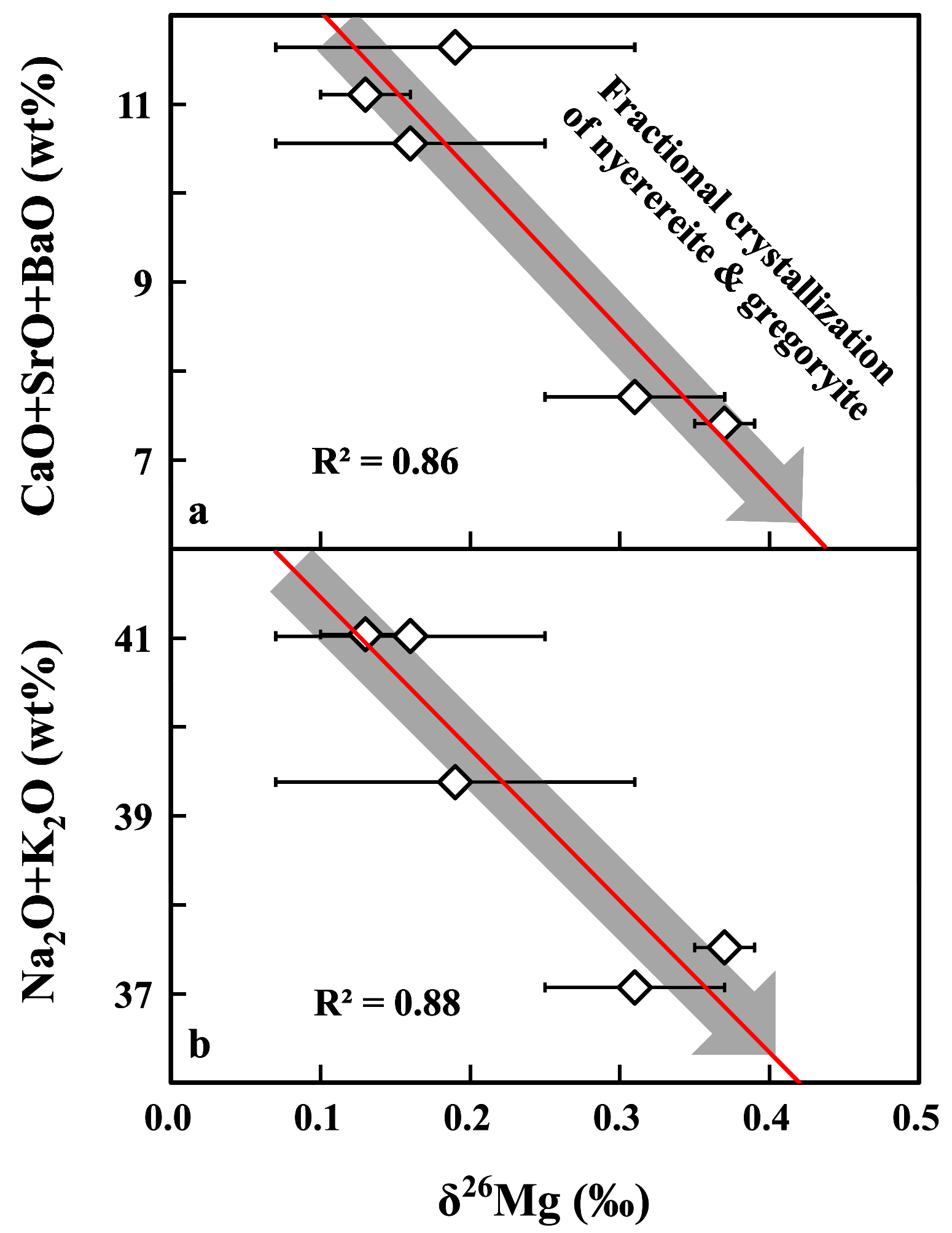

Fig. 5 